\title{
What are the Factors that Affect the Motivation of Digital Gamers?
}

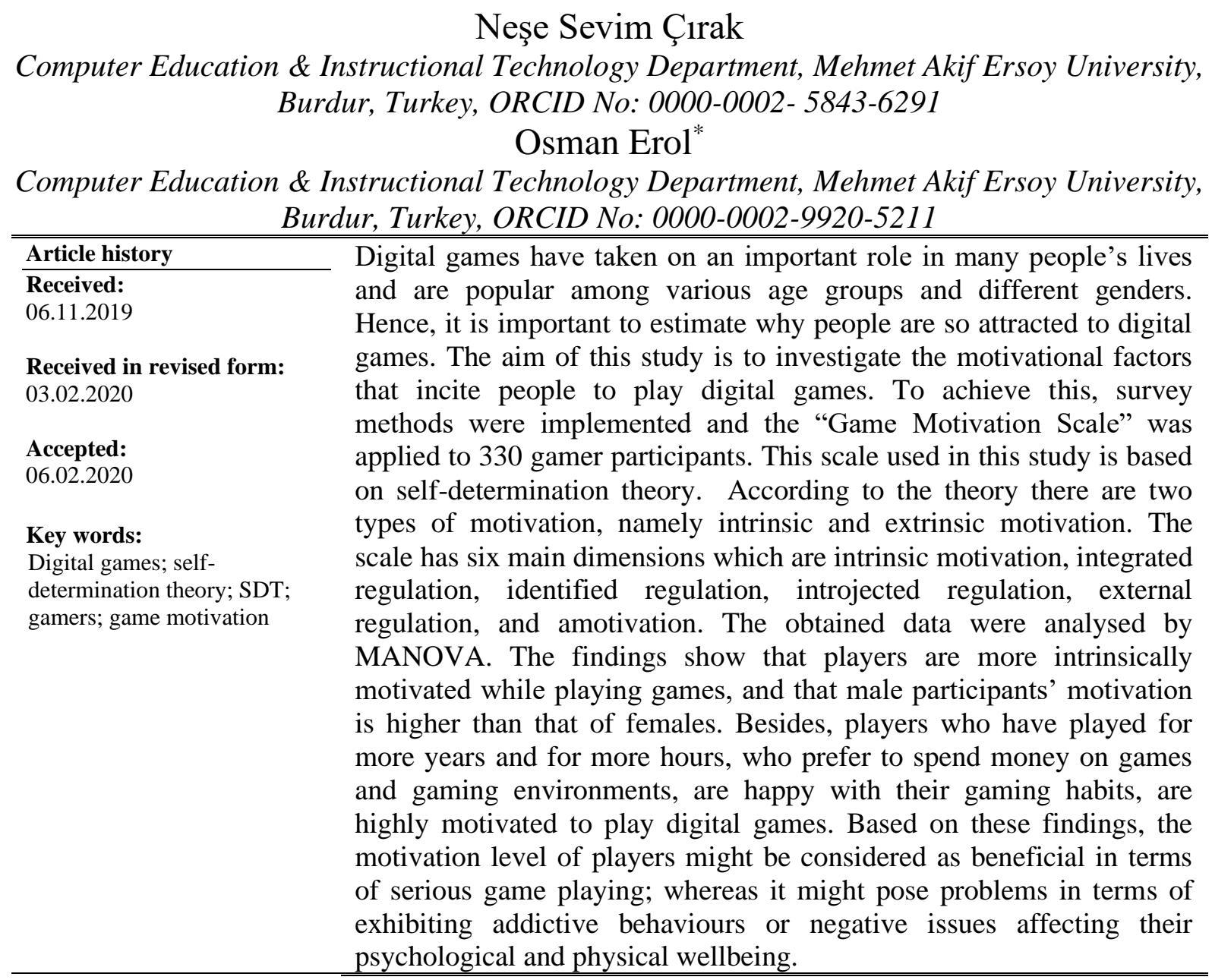

\section{Introduction}

Digital games have taken attention of many people around the world. Especially the advancement in computer technology and Internet connectivity permits designers and programmers to create various gaming environments that are complex and engaging, and which include numerous activities and goals (Ryan, Rigby, \& Przybylski, 2006). Hence it is shown that gaming has become popular among various age groups and genders (Interactive Software Federation of Europe, 2012; Gaming - Statistics \& Facts, 2019). Statistics have shown that a wide range of demographics participate in gaming, and that both the number of adult and young people spending their leisure time and energy on digital games is increasing rapidly. There are now more than 2.5 billion people play games across the World. In 2018, the 
value of the video-gaming market around the world was US\$137.9 billion and it is estimated that by 2019 that figure will rise to US\$ 152.1 billion (Newzoo, 2018). In 2017, 29\% of digital game-players were under 18 years of age, $27 \%$ were aged 18 to 35 years old, $19 \%$ were aged 36 to 49 years old, and $26 \%$ were 50 years or older. However, in $2015,14 \%$ of the players were under $18,15 \%$ of them were aged 18 to 35 years old, $19 \%$ were aged 25 to 34 years old, $22 \%$ were aged 35 to 44 years old, $14 \%$ were aged 45 to 54 years old, and $16 \%$ were aged 55 years or older (Gaming - Statistics \& Facts, 2019).

Similarly, it was seen that in $2006,62 \%$ of digital game players were male and $38 \%$ were female, but by 2017, 59\% were male and $41 \%$ were male (Gaming - Statistics \& Facts, 2019).Turkey is also an important market for game developers. The number of people that demand for digital games is increased in each day in Turkey (Digital Game Industry Report, 2016). In 2018, Turkish gamers spent US $\$ 129.1$ million on mobile games, US\$89.5million on downloaded games and US\$49.6 million on online games and it is expected that US\$292million will be spent in 2019. When the demographics of Turkish game players were examined, the statistics showed that generally male preferred to play digital games in Turkey. In $2017,68 \%$ of the gamers were male whereas $32 \%$ were female. Moreover, $28.4 \%$ of the players were aged 18 to 24 years old, $37.4 \%$ of them were aged 25 to $34,24.3 \%$ were between 35 and 44 years old and $9.9 \%$ were older than 45 years old. Finally, $30.8 \%$ of the Turkish gamers had low income, $34.6 \%$ medium and $34.6 \%$ had a high income (Gaming Statistics \& Facts, 2019).

The popularity of digital games among all age groups and genders is a cause of debate regarding the effects of digital game playing. Some researchers claim that playing digital games affects players negatively, whereas others support gaming experiences. The opponents of digital games argue that digital games can increase tendencies towards violence, damage players' psychological and physical health, decrease their productivity and achievement levels, and cause problems in familial and personal relationships (e.g., Anderson \& Bushman, 2001; Gentile \& Anderson, 2003). On the contrary, the proponents of gaming support that digital games psychologically benefit players, help them to feel a sense of efficacy and power (Jones, 2002), and also empowers their learning (Gee, 2003; Johnson, 2005). When the complexity and variety of games are taken into consideration, it can be claimed that games have the potential to give both harm and benefit the psychology of the players. Also according to Hamari and Keronen (2017), enjoyment and usefulness are important determinants for playing games.

Since millions of people engage in video gaming and their effects on gamers are questioned, it is very important to understand why they engage for a number of reasons (De Grove, Cauberghe, \& Van Looy, 2016). First of all, it helps to gain insight into the growing popularity of digital games as well as to gain an understanding of the motivational process of mediated human action. According to Malone (1980), people prefer to play because of factors such as "control," "challenge," "imaginary environment," and "curiosity." Similarly, Sherry, Lucas, Greenberg, and Lachlan (2006) described the reasons for playing in the context of "competition," "challenge," "social communication," "diversity," "rejuvenating effect," and "fantasy environments." Therefore, with emotions that emerge cognitively and emotionally within their own imaginary world, digital games can be attractive for individuals with characteristics such as self-competitiveness and competitiveness with others, and looking to challenging both themselves and against others (Pala \& Erdem, 2015). According to the published studies, another factor influencing game play is gender (Elliott, Ream, McGinskys \& Dunlap, 2012; Heeter, Lee, Medler \& Magerko, 2011; Hsieh, Lin \& Hou, 2016; Lowrie \& 
Jorgensen, 2011; Olsen, 2010; Paraskeva, Mysirlaki \& Papagianni, 2010; Rehbein, Staudt, Hanslmaier \& Kliem, 2016; Yang \& Quadir, 2018 ). Accordingly, males generally prefer to play digital games over females (Eglesz, Feteke, Kiss, \& Izso, 2005; Greenberg, Sherry, Lachlan, Lucas, \& Holmstrom, 2010; Hoffman \& Nadelson, 2010; İnal \& Çağıltay, 2005). According to Greenberg et al. (2010), factors such as challenge and social interaction motivate males more than females. Also, Eglesz et al. (2005) mentioned in their study that males more often than females are motivated by the challenges in videogames. In addition, male children prefer the aspects of control and personal victory more than female children when playing (Hamlen, 2011). Similar results have emerged in other studies where motivation is biologically diverse. Hoeft, Watson, Kesler, Bettinger, and Reiss (2008) examined the brain activities of 22 young game players during play. It was found that the male players were more actively centered about the reward and addiction in the brain than females during in-game activities (Hamlen, 2011). Additionally, understanding why people are so motivated by digital gaming provides a starting point as to investigate research questions related to concerns about the effects of digital gaming (Ferguson \& Olson, 2013).

Hence, this research aims to shed light on Turkish game players and reveal their gaming motivation. There is lack of research on the motivation of Turkish digital game players so it is believed that this study will help the researchers as well as game developers to gain insight about Turkish players. For all of these reasons, the current study aims to investigate the motivational factors that regulate gamers to play digital games. More specifically, the research questions of the current study are;

- What is the level of participants' game motivation towards digital games?

- Is there any significant difference between participants' game motivations in terms of gender?

- Is there any significant difference between participants' game motivations in terms of duration of game play?

- Is there any significant difference between participants' game motivations in terms of gaming platform?

- Is there any significant difference between participants' game motivations in terms of payment to play?

- Is there any significant difference between participants' game motivations in terms of willingness to change gaming habits?

\section{Literature Review}

The motivation of players towards game playing is one of the most investigated topics in game studies (Coursaris, Van Osch, \& Sese, 2016). However, few formal motivational theories have been applied to videogames, players' motivations, and the outcomes of gameplay (Demetrovics et al., 2011; King \& Delfabbro, 2009). Several researchers have attempted to gain insights into the motivation of players towards gaming, but in this research self-determination theory was used to evaluate the gamer motivations.

\section{Self Determination Theory}

Self-determination theory (SDT) is one of the theories proposed by Deci and Ryan (1985) in order to propose a framework for the wellbeing and motivation of people, and to assess both the levels and types of motivation. SDT highlights quantity versus quality of motivation as a means to analyze the consequences of active engagement. SDT claims that 
more adaptive outcomes will be gathered when an individual freely chooses participation in an activity in order to gain pleasure and enjoyment. The theory has been applied to several domains such as the work environment (Gagné \& Deci, 2005), sports (Vallerand, 2007), healthcare (Ryan, Patrick, Deci, \& Williams, 2008), and education (Deci, Vallerand, Pelletier, \& Ryan, 1991). In addition to these fields, some researchers used this theory to explain the motivation of gamers (Mills, Milyavskaya, Health \& Derevensky, 2018; Ryan et al., 2006; Seaborn \& Fels, 2015). SDT can be used to rationalize both the motivation of the players and their character or avatar in the gaming environment. In other words, SDT hypothesizes that a player makes choices between gaming products as well as the character chosen in the gaming environment (Frederick \& Ryan, 1993).

Self-determination theory proposes that motivation to the gaming can be explained by the psychological needs of people. According to SDT, the basic psychological needs are autonomy, competence, and relatedness (Deci \& Ryan, 1995). Autonomy refers to the willingness of an individual attending an activity at their own wish. Competence refers to the ability that a person feels to deal with the events in their environment. It is about the perception of an individual that their abilities match the activity. The theory proposes that a person needs challenges and wants to feel the competence to overcome such challenges. Relatedness refers to the sense that an individual connects with others while engaging in the activity (Ryan \& Deci, 2000, 2017). It describes the need of an individual to enter supportive social relationships. When individuals connect with others, they experience it (Ryan et al., 2006). According to Coursaris et al. (2016), in-game environment autonomy refers to controlling the game, competence refers to performance in the gaming environment, and relatedness is about the virtual relationships within the gaming environment. SDT emphasizes that an environment must fulfill these needs of an individual in order to develop a healthy sense of self which is not dependent on external sources in order to confirm their self-worth (Hodgins \& Knee, 2002). It is believed that the more an activity engagement fulfills these needs, the stronger the intrinsic motivation that occurs. (Ryan, 1995). Lafrenière, VernerFilion, and Vallerand (2012) stated that when an individual perceives that gaming fulfills these psychological needs, they develop more intrinsic motivation toward gaming. Likewise, several researchers have pointed out that higher need satisfaction in videogame engagement can yield stronger motivation to play, to more enjoyment, and to spending more time gaming (Johnson, Gardner, \& Sweetser, 2016; Ryan et al., 2006; Tamborini, Bowman, Eden, Grizzard, \& Organ, 2010). In other words, the appeal of the videogame can be predicted by the needs satisfaction of the gaming experience.

SDT offers two types of motivation, namely intrinsic and extrinsic. Intrinsic motivation is about the willingness to undertake an activity for the sake of itself, whereas extrinsic motivation refers to performing an activity not for the pleasure gained from the activity, but to receive or avoid something if separated from the activity (Deci \& Ryan, 1985, 2000). Players are intrinsically satisfied (Malone \& Lepper, 1987) or are just having "fun" while they are game playing (Bartle, 2004; Legault 2016; Wouters, van Nimwegen, van Oostendorp \& van Der Spek, 2013). Moreover, players who are intrinsically motivated to digital games play because they consider the game as enjoyable want to develop their own skill level, and like to experience the feeling of excitement and power that the game provides them (Lafrenière et al., 2012). The model suggests four types of extrinsic motivations; external regulation, introjected regulation, identified regulation and integrated regulation. External regulation is about the regulation of behavior due to external means such as rewards (Ryan, 1995). Introjected regulation regulates behavior by way of internal pressures like guilt and anxiety which are beyond the individual's control (Ryan \& Deci, 2000). In identified regulation, the behavior is 
regulated where game engagement suits the values or goals of the individual (Ryan, 1995). The behavior is structured out of choice (Lafrenière et al., 2012) and an individual engages to the activity if it fits their personal goals or it makes sense irrespective of whether the activity is fun or not (Koestner \& Losier, 2002). Finally, integrated regulation is about the personal expression of the individual in videogame engagement (Ryan \& Deci, 2017). In integrated regulation, an individual also attends to the activity out of choice; however, it is not limited to the activity level but it is about the organization of the self. In other words, the player is regulated to the game since regulation becomes the individual's habit and part of their sense of self. In addition to intrinsic and extrinsic motivation, Deci and Ryan (1985) suggest a third construct amotivation which refers the absence of motivation (Vallerand, 1997). In other words, it refers to a state in which a person is not motivated to behave or they behave in a way that is not intentionally regulated (Ryan \& Deci, 2017). SDT proposes that with the exception of amotivation, there is a positive relationship between the aforementioned motivations towards gaming and the time spent on gaming (Beard \& Wickham, 2016; Chua, Goh, \& Lim, 2019; Lafrenière et al., 2012; Mills, Milyavskaya, Health, \& Derevensky, 2018). The types of extrinsic regulations in SDT can be ordered in the self-determination continuum. It is claimed that from the lowest self-determination to the highest, the order is external regulation, introjection regulation, identification regulation, and integrated regulation. Likewise, intrinsic motivation has the highest self-determination, whereas amotivation has the lowest. SDT proposes that intrinsic motivation is the main motivation in both play and sport (Frederick \& Ryan, 1993), as well as for digital gaming since players do not attain extra approval or rewards for playing the game.

\section{Method}

Survey method was implemented in this study in order to understand the motivational factors that affect players in continuing to play digital games. Survey method aims to understand or describe the attitudes, beliefs, characteristics, or behaviors of the population by applying several questions to the sample or population (Creswell, 2009; Fraenkel, Wallen, \& Hyun, 2012); hence, it is claimed that survey method is the most appropriate method for the aim of this study.

\section{Participants of the Study}

In this study, the participants consisted of 330 gamers, $73.2 \%(n=257)$ of whom are male and $26.8 \%(n=94)$ are female, and range in age from 18 to 34 years old $(M=22.42$; $\mathrm{SD}=11.92$ ). Many of the participants in this study are young gamers. The majority of the players have computers (92.9\%), while most of them have used computers for four to six years $(31.1 \%)$ and/or played digital games $(29.1 \%)$ for four to six years. Table 1 details the participants' demographic characteristics.

Table 1. Demographic characteristics of participants

\begin{tabular}{llllllll}
\hline $\begin{array}{l}\text { Variable } \\
\text { Educational Level }\end{array}$ & $\boldsymbol{n}$ & $\boldsymbol{F}$ & $\begin{array}{l}\text { Variable } \\
\text { Game Type }\end{array}$ & $\begin{array}{l}\text { Female } \\
\boldsymbol{n}\end{array}$ & $\boldsymbol{F}$ & $\begin{array}{l}\text { Male } \\
\boldsymbol{n}\end{array}$ \\
\hline Primary school & 3 & $0.9 \%$ & Action & 42 & $44.7 \%$ & 195 & $75.9 \%$ \\
Secondary school & 10 & $2.8 \%$ & Adventure & 37 & $39.4 \%$ & 137 & $53.3 \%$ \\
High school & 70 & $19.9 \%$ & Fight & 8 & $8.5 \%$ & 111 & $43.2 \%$ \\
Associate Degree & 54 & $15.4 \%$ & Puzzle & 55 & $58.5 \%$ & 66 & $25.2 \%$ \\
Undergraduate degree & 195 & $55.6 \%$ & RPG & 27 & $28.7 \%$ & 120 & $46.7 \%$ \\
Graduate degree & 19 & $5.4 \%$ & Simulation & 33 & $35.1 \%$ & 92 & $35.8 \%$ \\
PC Ownership & & & Sport & 8 & $8.5 \%$ & 123 & $47.9 \%$
\end{tabular}




\begin{tabular}{|c|c|c|}
\hline Yes & 326 & $92.9 \%$ \\
\hline No & 22 & $6.3 \%$ \\
\hline \multicolumn{3}{|c|}{ Duration of Computer usage } \\
\hline Less than 1 year & 9 & $2.6 \%$ \\
\hline $1-3$ years & 54 & $15.4 \%$ \\
\hline $4-6$ years & 109 & $31.1 \%$ \\
\hline $7-9$ years & 86 & $24.5 \%$ \\
\hline 10 years and above & 93 & $26.5 \%$ \\
\hline
\end{tabular}

\begin{tabular}{|c|c|c|c|c|}
\hline \multirow{2}{*}{\multicolumn{5}{|c|}{$\begin{array}{cc}\text { Strategy } & 33 \\
\text { Platform Gamers Played }\end{array}$}} \\
\hline & & & & \\
\hline Internet & 54 & $57.4 \%$ & 146 & $56.8 \%$ \\
\hline PC & 70 & $74.5 \%$ & 241 & $93.8 \%$ \\
\hline Console & 14 & $14.9 \%$ & 108 & $42 \%$ \\
\hline Remote & 5 & $5.3 \%$ & 48 & $18.7 \%$ \\
\hline Mobile & 73 & $77.7 \%$ & 150 & $58.4 \%$ \\
\hline \multicolumn{5}{|c|}{ Daily game playing duration } \\
\hline$\leq 2$ hours & 54 & $60.7 \%$ & 69 & $28.6 \%$ \\
\hline 3-6 hours & 28 & $31.5 \%$ & 114 & $47.53 \%$ \\
\hline$\geq 7$ hours & 7 & $7.9 \%$ & 58 & $24.1 \%$ \\
\hline \multicolumn{5}{|c|}{ Duration of Digital Game Playing } \\
\hline$<1$ year & 33 & $37,1 \%$ & 11 & $4,6 \%$ \\
\hline $1-3$ years & 28 & $31,5 \%$ & 64 & $26,6 \%$ \\
\hline 4-6 years & 17 & $19,1 \%$ & 77 & $32,0 \%$ \\
\hline $7-9$ years & 10 & $11,2 \%$ & 47 & $19,5 \%$ \\
\hline$>10$ years & 1 & $1,1 \%$ & 42 & $17,4 \%$ \\
\hline
\end{tabular}

\section{Data Collection and Analysis}

The data in this study was collected from gamers in Turkey via an online questionnaire. The scale used in this study was developed in the English language by Lafrenière et al. (2012) based on self-determination theory, and was later translated and adapted to Turkish by Akin, Kaya, and Demirci (2015). The scale consists of 18 five-point, Likert-type items under six factors "intrinsic motivation," "integrated regulation," "identified regulation," "introjected regulation," "external regulation," and "amotivation." In addition, 13 demographics questions were included in order to gain information about the participants such as gender, age, education level, pc ownership, duration of pc usage and gameplay in years, types of played games, preferred gaming platforms etc.

The online questionnaire was prepared by the researchers and delivered via forums and Facebook pages that digital game players enrolled. The aims of the study were included in the questionnaire and voluntary participants were asked to complete it as accurately as possible. Completion of the questionnaire took between 15 and 20 minutes. The obtained data were coded and analyzed by IBM SPSS 21 statistical package. In this study, inferential statistics were used to analyze the data. Multivariate analysis of variance (MANOVA) test was conducted in order to identify whether or not there was a significant difference among players in their motivation towards gaming based on variables of gender, duration of gameplay in years, preferred gaming platforms, duration of longest playing time, whether or not players pay money to play a game or buy an item in the game environment, and willingness to change their gaming habits. The six sub-factors were identified as the dependent variable of the study. Prior to performing the MANOVA tests, the assumptions of MANOVA test, normality of dependent variables, correlation, equality of covariance matrices, and independence of observation outliers were checked and it was seen that all the assumptions were satisfactorily met. Instead of Wilks Lambda, Pillai's trace was preferred in order to identify any differences among the participants because of its known robustness (Hair, Black, Babin, Anderson, \& Tatham, 2006). Finally, Bonferonni correction was applied in post hoc tests. 


\section{Findings}

\section{Gaming motivation of players}

Table 2. Level of participants' gaming motivation

\begin{tabular}{llllll}
\hline & $N$ & Min & Max & $M$ & $S D$ \\
\hline Intrinsic motivation & 330 & 1.00 & 7.00 & 4.1242 & 1.78639 \\
Integrated regulation & 330 & 1.00 & 7.00 & 3.2505 & 1.92599 \\
Identified regulation & 330 & 1.00 & 7.00 & 3.2303 & 1.81484 \\
Introjected regulation & 330 & 1.00 & 7.00 & 3.5394 & 1.82629 \\
External regulation & 330 & 1.00 & 7.00 & 3.3394 & 1.89169 \\
Amotivation & 330 & 1.00 & 7.00 & 3.4182 & 1.72282 \\
Total: Game Motivation & 330 & 1.11 & 6.61 & 3.4837 & 1.43638 \\
\hline
\end{tabular}

According to Table 2, participants' gaming motivation appears to be at the middle interval level $(M=3.48 ; S D=1.44)$. It can also be seen that participants' intrinsic motivation level $(M=4.12 ; S D=1.79)$ is highest, whereas integrated regulation $(M=3.25 ; S D=1.93)$ and identified regulation $(\mathrm{M}=3.23 ; \mathrm{SD}=1.81)$ motivation levels are the lowest.

\section{Effects of gender on gaming motivation}

Table 3. Effects of gender on gaming motivation

\begin{tabular}{llllllll}
\hline Variable & Gender & $N$ & $M$ & $S D$ & $F$ & $p$ & $\eta^{2}$ \\
\hline Intrinsic motivation & Female & 89 & 3.63 & 1.84 & $9.454^{*}$ & .002 & .028 \\
& Male & 241 & 4.30 & 1.73 & & & \\
Integrated regulation & Female & 89 & 2.54 & 1.86 & $17.641^{*}$ & .000 & .051 \\
& Male & 241 & 3.51 & 1.89 & & & \\
Identified regulation & Female & 89 & 2.71 & 1.74 & $10.387^{*}$ & .001 & .031 \\
& Male & 241 & 3.42 & 1.81 & & & \\
Introjected regulation & Female & 89 & 2.95 & 1.74 & $13.275^{*}$ & .000 & .039 \\
& Male & 241 & 3.76 & 1.81 & & & \\
External regulation & Female & 89 & 2.49 & 1.68 & $26.429^{*}$ & .000 & .075 \\
& Male & 241 & 3.65 & 1.87 & & & \\
Amotivation & Female & 89 & 3.25 & 1.81 & 1.149 & .285 & .003 \\
& Male & 241 & 3.48 & 1.69 & & & \\
\hline
\end{tabular}

Pillai's trace $=.083, F[6-323]=4.882, \eta^{2}=.083, p<.05$

$* p<.0083$

A one-way between-groups MANOVA was conducted in order to examine the effect of gender on game motivation. The Pillai's trace result showed a significant effect of gender on game motivation $\mathrm{F}(6,323)=4.882, \mathrm{p}<.05$; Pillai's trace $=.083$; partial $\eta 2=.083$. The post hoc tests showed that male players had significantly higher mean scores in intrinsic motivation, integrated regulation, identified regulation, introjected regulation, and external regulation than female players (Table 3 ). 


\section{Effects of duration of gameplay on gaming motivation}

Table 4. Effects of duration of gameplay in years on gaming motivation

\begin{tabular}{|c|c|c|c|c|c|c|c|}
\hline Variable & $\begin{array}{l}\text { Duration } \\
\text { (years) }\end{array}$ & $n$ & $M$ & $S D$ & $F$ & $p$ & $\eta^{2}$ \\
\hline \multirow[t]{2}{*}{ Intrinsic motivation } & $\leq 3$ & 136 & 3.53 & 1.60 & 27.734 & .000 & .078 \\
\hline & $\geq 4$ & 194 & 4.54 & 1.79 & & & \\
\hline \multirow[t]{2}{*}{ Integrated regulation } & $\leq 3$ & 136 & 2.67 & 1.60 & 22.253 & .000 & .064 \\
\hline & $\geq 4$ & 194 & 3.66 & 2.03 & & & \\
\hline \multirow[t]{2}{*}{ Identified regulation } & $\leq 3$ & 136 & 2.76 & 1.53 & 16.093 & .000 & .047 \\
\hline & $\geq 4$ & 194 & 3.56 & 1.93 & & & \\
\hline \multirow[t]{2}{*}{ Introjected regulation } & $\leq 3$ & 136 & 3.08 & 1.56 & 15.554 & .000 & .045 \\
\hline & $\geq 4$ & 194 & 3.86 & 1.93 & & & \\
\hline \multirow[t]{2}{*}{ External regulation } & $\leq 3$ & 136 & 2.89 & 1.59 & 13.727 & .000 & .040 \\
\hline & $\geq 4$ & 194 & 3.66 & 2.02 & & & \\
\hline \multirow[t]{2}{*}{ Amotivation } & $\leq 3$ & 136 & 3.45 & 1.54 & .072 & .789 & .000 \\
\hline & $\geq 4$ & 194 & 3.40 & 1.85 & & & \\
\hline
\end{tabular}

In order to examine the effects of duration of game play on game motivation, a one-way between-groups MANOVA was conducted and the Pillai's trace result showed a significant effect of gender on game motivation $\mathrm{F}(6,323)=5.143, \mathrm{p}<.05$; Pillai's trace $=.087$; partial $\eta 2=.087$. Moreover, as seen in Table 4 . the post hoc test showed that players who played games for four years or more had significantly higher mean scores in intrinsic motivation, integrated regulation, identified regulation, introjected regulation, and external regulation than the players who played three years or less.

\section{Effects of gaming platform on gaming motivation}

Table 5. Effects of Internet game play on gaming motivation

\begin{tabular}{llllllll}
\hline Variable & $\begin{array}{l}\text { Play Internet } \\
\text { Games }\end{array}$ & $n$ & $M$ & $S D$ & $F$ & $p$ & $\eta^{2}$ \\
& Yes & 189 & 4.60 & 1.66 & 35.375 & .000 & .097 \\
\hline Intrinsic motivation & No & 141 & 3.48 & 1.75 & & & \\
& Yes & 189 & 3.79 & 1.89 & 37.860 & .000 & .103 \\
Integrated regulation & No & 141 & 2.53 & 1.75 & & & \\
& Yes & 189 & 3.72 & 1.76 & 36.382 & .000 & .100 \\
Identified regulation & No & 141 & 2.57 & 1.67 & & & \\
& Yes & 189 & 4.11 & 1.75 & 50.131 & .000 & .133 \\
Extrojected regulation & No & 141 & 2.77 & 1.63 & & & \\
& Yes & 189 & 3.84 & 1.83 & 34.020 & .000 & .094 \\
Amotivation & No & 141 & 2.67 & 1.77 & & & \\
& Yes & 189 & 3.65 & 1.75 & 8.241 & .004 & .025 \\
& No & 141 & 3.11 & 1.65 & & & \\
\hline
\end{tabular}

Pillai's trace $=.15, F[6,323]=9.474, p<.05 ; \eta^{2}=.15$

$* p<.0083$ 
One-way between-groups MANOVA was conducted in order to examine whether or not playing games on the Internet affected gaming motivation. The results showed that gaming platform had a significant effect on gaming motivation. The Pillai's trace result showed a significant effect of playing Internet games on gaming motivation $F(6,323)=9.474, p<.05$; Pillai's trace $=.15$; partial $\eta 2=.15$. Players who played games on the Internet had significantly higher mean scores in intrinsic motivation, integrated regulation, identified regulation, introjected regulation, external regulation, and amotivation than players who did not play games on the Internet (Table 5).

Table 6. Effects of console gameplay on gaming motivation

\begin{tabular}{llllllll}
\hline Variable & $\begin{array}{l}\text { Console } \\
\text { gameplay }\end{array}$ & $n$ & $M$ & $S D$ & $F$ & $p$ & $\eta^{2}$ \\
\hline Intrinsic motivation & Yes & 110 & 4.84 & 1.70 & 28.404 & .000 & .080 \\
& No & 220 & 3.77 & 1.72 & & & \\
Integrated regulation & Yes & 110 & 3.99 & 1.96 & 26.489 & .000 & .075 \\
& No & 220 & 2.88 & 1.80 & & & \\
Identified regulation & Yes & 110 & 3.84 & 1.90 & 19.638 & .000 & .056 \\
& No & 220 & 2.93 & 1.69 & & & \\
Introjected regulation & Yes & 110 & 4.47 & 1.94 & 48.704 & .000 & .129 \\
& No & 220 & 3.08 & 1.58 & & & \\
External regulation & Yes & 110 & 4.09 & 1.95 & 28.194 & .000 & .079 \\
& No & 220 & 2.97 & 1.75 & & & \\
Amotivation & Yes & 110 & 3.79 & 1.93 & 7.885 & .005 & .023 \\
& No & 220 & 3.23 & 1.58 & & & \\
\hline
\end{tabular}

Pillai's trace $=.14, F(6,323)=8.421, p<.05 ; \eta^{2}=.14$

$* p<.0083$

Similarly, the Pillai's trace result in the one-way between-groups MANOVA test showed a significant difference on gaming motivation among players who played console games $\mathrm{F}(6,323)=8.421, \mathrm{p}<.05$; Pillai's trace $=.14$; partial $\eta 2=.14$. Like Internet game players, console game players significantly had higher mean scores in intrinsic motivation, integrated regulation, identified regulation, introjected regulation, and external regulation over players of other platforms (Table 6).

Table 7. Effects of mobile game play on gaming motivation

\begin{tabular}{llllllll}
\hline Variable & $\begin{array}{l}\text { Mobile } \\
\text { Gameplay }\end{array}$ & $n$ & $M$ & $S D$ & $F$ & $p^{*}$ & $\eta^{2}$ \\
& Yes & 208 & 4.46 & 1.81 & 21.729 & .000 & .062 \\
Intrinsic motivation & No & 122 & 3.54 & 1.60 & & & \\
& Yes & 208 & 3.56 & 2.02 & 15.411 & .000 & .045 \\
Integrated regulation & No & 122 & 2.72 & 1.63 & & & \\
& Yes & 208 & 3.47 & 1.89 & 9.635 & .002 & .029 \\
Identified regulation & No & 122 & 2.83 & 1.60 & & & \\
& Yes & 208 & 3.96 & 1.91 & 33.260 & .000 & .092 \\
Introjected regulation & No & 122 & 2.82 & 1.42 & & & \\
External regulation & Yes & 208 & 3.60 & 1.99 & 10.947 & .001 & .032 \\
& No & 122 & 2.90 & 1.62 & & & \\
Amotivation & Yes & 208 & 3.60 & 1.73 & 6.670 & .010 & .020 \\
& No & 122 & 3.10 & 1.67 & & & \\
\hline
\end{tabular}


Pillai's trace $=.10 ; F(6,323)=6.155 ; p<.05 ; \eta^{2}=.10$

$* p<.0083$

Finally, the Pillai's trace result in the one-way between-groups MANOVA showed a significant effect of playing mobile games on gaming motivation $\mathrm{F}(6,323)=6.155, \mathrm{p}<.05$; Pillai's trace $=.10$; partial $\eta 2=.10$. Players who played mobile games significantly had higher mean scores in intrinsic motivation, integrated regulation, identified regulation, introjected regulation, and external regulation than players who did not play mobile games (Table 7).

\section{Effects of pay to play on gaming motivation}

Table 8. Effects of money spent or buy an item on gaming motivation

\begin{tabular}{llllllll}
\hline Variable & Pay to play & $N$ & $M$ & $S D$ & $F$ & $p^{*}$ & $\eta^{2}$ \\
\hline Intrinsic motivation & Yes & 145 & 4.78 & 1.86 & 38.470 & .000 & .105 \\
& No & 185 & 3.61 & 1.55 & & & \\
Integrated regulation & Yes & 145 & 3.98 & 2.11 & 41.607 & .000 & .113 \\
& No & 185 & 2.68 & 1.55 & & & \\
Identified regulation & Yes & 145 & 3.75 & 1.98 & 22.336 & .000 & .064 \\
& No & 185 & 2.83 & 1.56 & & & \\
Introjected regulation & Yes & 145 & 4.22 & 1.91 & 39.687 & .000 & .108 \\
& No & 185 & 3.01 & 1.57 & & & \\
External regulation & Yes & 145 & 4.03 & 1.93 & 38.091 & .000 & .104 \\
& No & 185 & 2.80 & 1.68 & & & \\
Ammotivation & Yes & 145 & 3.41 & 1.83 & .004 & .950 & .000 \\
& No & 185 & 3.42 & 1.64 & & & \\
\hline
\end{tabular}

Pillai's trace $=.15 ; F(6,323)=9.408 ; p<.05 ; \eta^{2}=.15$

$* p<.0083$

The one-way between-groups MANOVA was conducted in order to examine whether or not payment to play a game or buy an item in the game environment affected gaming motivation. The Pillai's trace result show a significant effect of payment on gaming motivation $\mathrm{F}(6,323)=9.408, \mathrm{p}<.05$; Pillai's trace $=.15$; partial $\eta 2=.15$. It can be seen that players who spent money for games or to buy an item in the game environment significantly had higher mean scores in intrinsic motivation, integrated regulation, identified regulation, introjected regulation, and external regulation than players who did not spend money (Table 8).

\section{Effects of duration of longest playing time on gaming motivation}

Table 9. Effects of duration of longest playing time on gaming motivation

\begin{tabular}{lclllllll}
\hline Variable & $\begin{array}{l}\text { Duration } \\
\text { (hours) }\end{array}$ & $n$ & $M$ & $S D$ & $F$ & $p^{*}$ & $\eta^{2}$ & Post hoc** \\
\hline Intrinsic & $\leq 2$ & 123 & 3.47 & 1.65 & 19.059 & .000 & .104 & $3>2>1$ \\
motivation & $3-6$ & 142 & 4.28 & 1.61 & & & & \\
& $\geq 7$ & 65 & 5.02 & 1.94 & & & & \\
\hline Integrated & $\leq 2$ & 123 & 2.73 & 1.69 & 14.802 & .000 & .083 & $3>2,3>1$ \\
regulation & $3-6$ & 142 & 3.23 & 1.76 & & & &
\end{tabular}




\begin{tabular}{lclllllll}
\hline Variable & $\begin{array}{l}\text { Duration } \\
\text { (hours) }\end{array}$ & $n$ & $M$ & $S D$ & $F$ & $p^{*}$ & $\eta^{2}$ & Post hoc** \\
\hline & $\geq 7$ & 65 & 4.28 & 2.29 & & & & \\
\hline Identified regulation & $\leq 2$ & 123 & 2.94 & 1.73 & 5.890 & .003 & .035 & $3>2,3>1$ \\
& $3-6$ & 142 & 3.19 & 1.59 & & & & \\
& $\geq 7$ & 65 & 3.87 & 2.25 & & & & \\
\hline Introjected & $\leq 2$ & 123 & 2.89 & 1.73 & 14.818 & .000 & .083 & $3>1,2>1$ \\
regulation & $3-6$ & 142 & 3.78 & 1.61 & & & & \\
& $\geq 7$ & 65 & 4.23 & 2.07 & & & & \\
\hline External regulation & $\leq 2$ & 123 & 2.73 & 1.78 & 10.885 & .000 & .062 & $3>1,2>1$ \\
& $3-6$ & 142 & 3.67 & 1.79 & & & & \\
\hline Amotivation & $\geq 7$ & 65 & 3.77 & 2.04 & & & & \\
& $\leq 2$ & 123 & 3.46 & 1.75 & 6.313 & .002 & .037 & $1>3,2>3$ \\
& $3-6$ & 142 & 3.68 & 1.64 & & & & \\
\hline
\end{tabular}

Pillai's trace $=.23 ; F(12,646)=6.986, p<.05 ;$ partial $\eta^{2}=.15$

$* p<.0083$

$* * 1: \leq 2$ hours, $2: 3-6$ hours, $3 ; \geq 7$ hours

In order to analyze the effects of duration of the longest paying time on gaming motivation, a one-way between-groups MANOVA was conducted and a significant effect was seen for longest playing time on gaming motivation $\mathrm{F}(12,646)=6.986, \mathrm{p}<.05$; Pillai's trace $=.23$; partial $\eta 2=.15$. Post hoc tests revealed significant differences between players who played for more than seven hours in intrinsic motivation, integrated regulation, identified regulation, introjected regulation, and external regulation. On the contrary, it was seen that players who spent at least seven hours in a gaming environment were significantly less amotivated to games compared to others.

\section{Effects of willingness to change gaming habits on gaming motivation}

Table 10. Effects of willingness to change gaming habits on motivation

\begin{tabular}{lllllllll}
\hline Variable & $\begin{array}{l}\text { Willingness to } \\
\text { change gaming } \\
\text { habits }\end{array}$ & & & & & & & \\
& & & & & & & \\
\hline Intrinsic motivation & Yes & 65 & 3.17 & 1.59 & 16.327 & .000 & .091 & $3>2>1$ \\
& Maybe & 88 & 3.95 & 1.80 & & & & \\
& No & 177 & 4.56 & 1.70 & & & & \\
\hline Integrated & Yes & 65 & 2.38 & 1.51 & 15.308 & .000 & .086 & $3>2,3>1$ \\
regulation & Maybe & 88 & 2.89 & 1.85 & & & & \\
& No & 177 & 3.75 & 1.95 & & & & \\
\hline Identified & Yes & 65 & 2.46 & 1.41 & 14.834 & .000 & .083 & $3>2,3>1$ \\
regulation & Maybe & 88 & 2.85 & 1.59 & & & & \\
& No & 177 & 3.70 & 1.92 & & & & \\
\hline Introjected & Yes & 65 & 2.83 & 1.69 & 11.357 & .000 & .065 & $3>2,3>1$ \\
regulation & Maybe & 88 & 3.23 & 1.71 & & & & \\
& No & 177 & 3.95 & 1.83 & & & & \\
\hline External regulation & Yes & 65 & 2.79 & 1.72 & 10.323 & .000 & .059 & $3>2,3>1$ \\
& Maybe & 88 & 2.88 & 1.80 & & & &
\end{tabular}




\begin{tabular}{lllllllll} 
& No & 177 & 3.77 & 1.90 & & & & \\
\hline Amotivation & Yes & 65 & 4.15 & 1.80 & 7.681 & .001 & .045 & $1>2,1>3$ \\
& Maybe & 88 & 3.17 & 1.52 & & & & \\
& No & 177 & 3.27 & 1.73 & & & & \\
\hline
\end{tabular}

Pillai's trace $=.19 ; F(12,646)=5.536 ; p<.05 ; \eta^{2}=.09$

$* p<.0083$

** 1: Yes, 2: Maybe, 3: No

A one-way between-groups MANOVA was conducted in order to examine whether or not the willingness to change gaming habits affected gaming motivation. The Pillai's trace result showed a significant effect of willingness to change gaming habits on gaming motivation $\mathrm{F}(12,646)=5.536, \mathrm{p}<.05$; Pillai's trace $=.19$; partial $\eta 2=.09$. Post hoc tests revealed significant differences between players who did not want to give up their playing habits and the others in intrinsic motivation, integrated regulation, identified regulation, introjected regulation, and external regulation. In contrast, players who wanted to give up their playing habits were significantly more amotivated towards the game compared to other players.

\section{Discussion and Conclusions}

This study aims to examine the motivation of Turkish players through an online survey applied to 330 digital gamers. The survey was designed based on self-determination theory which is one of the most established theoretical frameworks that used in game motivation researches (Mills, Milyavskaya, Health \& Derevensky, 2018; Seaborn \& Fels, 2015). It is revealed that the motivation of participants in this study is generally in the middle range. First, according to the findings, it is seen that the intrinsic motivation of the participants is higher than external motivations (external regulation, introjected regulation, identified regulation, integrated regulation). People are intrinsically motivated and spend more time and energy to complete an activity if they enjoy the activity (Legault 2016; Wouters, van Nimwegen, van Oostendorp \& van Der Spek, 2013). Based on this finding, it can be said that the players are more intrinsically motivated towards digital gaming, and that they play games in order to develop their own skills, for their enjoyment, and to feel excitement and power provided through the game as suggested by Lafrenière et al. (2012). However, interestingly, the current study also found that amotivation level of some participants was higher than some extrinsic motivation factors. Lafrenière et al. (2012) defines amotivation as the relative absence of intrinsic or extrinsic motivation. Amotivation is expected to have the lowest effect on the increase of gaming motivation. But the literature provided some empirical evidence that amotivation also increase the players' motivation to the game significantly and even might cause game addiction. Some studies showed a positive relationship between amotivation and game addiction (Beard \& Wickham, 2016; Chua, Goh, \& Lim, 2019; Mills, Milyavskaya, Health, \& Derevensky, 2018). The researchers claim that the high level of the amotivation can increase time people spend on digital games, as well as leads problematic game playing because players might develop a strong attachment of selfesteem to the engagement on gaming even though they are amotivated to the game. Hence, it might be said that some of the participants in the current study were amotivated or motivated intrinsically to gaming not extrinsically.

Gaming studies show that many variables influence the motivation of players and their willingness to play, with gender one of the most determining variables in game motivation. Gender differences affects the game preferences, players' performance and achievement in game environment significantly. In fact, gender plays a significant role in whole digital 
gaming process. Paraskeva, Mysirlaki and Papagianni (2010) claims that gender affects the use of games such as game preferences and game playing habits. For instance, Lowrie and Jorgensen (2011) and Rehbein, Staudt, Hanslmaier and Kliem (2016) showed that males spent more time on playing games than women. But, Hsieh Lin and Hou (2016) and Yang and Quadir (2018) found that boys had less gaming flow experience than girls. In our study male participants spend more time on playing games compared to female. Regarding with game preferences, Heeter, Lee, Medler, and Magerko (2011) claims that males put great emphasis on performance while females are considered as low-level performers. According to researchers exploration and achievement affect the female players' motivation less than male players. In addition Rehbein, Staudt, Hanslmaier, \& Kliem, (2016) claims that male prefer shooter, role-playing and strategy games whereas female choose to play more casual and brain-and-skill-oriented games like puzzles (Elliott, Ream, McGinskys \& Dunlap, 2012). This study reveals similar findings and shows that female participants prefer puzzle and actions games whereas male prefer action, strategy and adventure games.

The current study showed male participants as more motivated to gaming than female participants, which is consistent with previous studies found in the literature (Eglesz et al., 2005; Greenberg et al., 2010; Hoffman \& Nadelson, 2010; İnal \& Çağıltay, 2005). The reason for this may be that male gamers seek "challenge" and "victory" in their games more than females (Eglesz et al., 2005; Olsen, 2010). So, when examined biologically, the brain structure of male gamers, who's focus is addiction and rewards, is more active than female gamers during play (Hoeft et al., 2008); and so it may therefore be proposed that male gamers have a higher tendency towards gaming addiction than female gamers.

Another factor that influences the motivation of players is gaming experience. In this context, based on the findings of the current study, it can be said that experienced participants have higher motivation to play games. In addition, this study suggests that the environment or tools which players use to play digital games is important in terms of player motivation. It was seen that the motivations of online players are higher than those who do not play games via the Internet. The possibility in online games to compete with other players and create a challenging environment may be the cause of this significant difference among the players. In addition to this, the current study showed that the motivation of console game players and mobile game players was high. Since, many people carry their mobile phones with them at all times and to any place, they can access their games at any time which increases the duration of their gaming sessions and which may positively affect the motivation of the players. In the current study, it was seen that the frequency of playing games also increased the motivation for game playing. Also the current study showed that players who spent money for games or to buy an item in the game environment have been more motivated. However according to Hamari (2015) there is a negative relation between enjoyment of game and willingness to buy virtual goods. In addition, there is also the opposite situation in the amotivation factors. In the findings of the current study, it was seen that the motivation of participants who do not want to give up their gaming habits was higher than those who either want to give up or are undecided. The reason for this may be that playing games over many hours causes players to acquire a habit of indispensable game playing sessions; and this habit maintains the players' motivation as high.

This study is conducted with only 330 gamers. For this reason the readers should take the number of the participants in to the consideration while interpreting the results. It is therefore suggested that similar studies should be conducted with more players. 
Based on the findings of the current study, it was seen that the motivation of gamer participants in this study can be influenced by many variables, including gender, playing experience, and duration. Hence, these variables should be taken into account in studies on gaming motivation; and that how these variables affect motivation should be investigated deeply in future studies. This focus might help researchers to identify the motivational factors of digital games. Also, in the current study, both online and offline gamers' motivation were investigated. In future research, only the motivation of online gamers could be examined in order to see how the motivational factors identified in self-determination theory affect them in detail. Additionally, a similar study could be conducted with adolescents in order to see whether or not there are any differences between adolescent and adult digital gamers in terms of motivational factors. Finally, STD claims that motivation to the gaming can be explained by psychological needs of people which are autonomy, competence and relatedness. So, the relationship between these needs of gamers should be investigated in detail in the future.

\section{References}

Akin, A., Kaya, Ç., \& Demirci, I. (2015). The Validity and Reliability of the Gaming Motivation Scale. Mersin University Journal of the Faculty of Education, 11(1), 1831.

Anderson, C. A., \& Bushman, B. J. (2001). Effects of violent video games on aggressive behavior, aggressive cognition, aggressive affect, physiological arousal, and prosocial behavior: A meta-analytic review of the scientific literature. Psychological science, 12(5), 353-359.

Bartle, R. A. (2004). Designing virtual worlds. Berkeley, CA: New Riders.

Beard, C. L., \& Wickham, R. E. (2016). Gaming-contingent self-worth, gaming motivation, and internet gaming disorder. Computers in Human Berhavior, 61, 507-515. doi:10.1016/j.chb.2016.03.046

Chua, H. M., Goh, X. Y., \& Lim, Z. Y. (2019). The impact of game engagement and game motivation on game addiction among the young adult multiplayer online battle arena players in Malaysia, Unpublished Doctoral dissertation, UTAR.

Coursaris, C. K., Van Osch, W., \& Sese, F. (2016). Exploring the Empirical Link Between Game Features, Player Motivation, and Game Behavior. In MCIS (Mediterranean Conference on Information Systems) Proceedings (p. 53). Nicosia, Cyprus: University Of Nicosia.

Creswell, J. W. (2009). Research Design: Qualitative, Quantitative, and Mixed Methods Approaches (3rd ed.), SAGE Publications.

Deci, E. L., \& Ryan, R. M. (1985). Intrinsic motivation and self-determination in human behavior. New York, NY: Plenum Press.

Deci, E., \& Ryan, R. M. (1995). Human autonomy: the basis for true self-esteem. In M. Kernis (Ed.), Efficacy, agency, and self-esteem (pp. 31e49). New York: Plenum Press.

Deci, E. L., \& Ryan, R. M. (2000). The "what" and "why" of goal pursuit: Human needs and the self-determination of behavior. Psychological Inquiry, 11(4), 227-268. https://www.tandfonline.com/doi/pdf/10.1207/S15327965PLI1104_01?needAccess=tr ue\&

Deci, E. L., Vallerand, R. J., Pelletier, L. G., \& Ryan, R. M. (1991). Motivation and education: The self-determination perspective. Educational Psychologist, 26(3-4), 325-346.

De Grove, F., Cauberghe, V., \& Van Looy, J. (2016). Development and validation of an instrument for measuring individual motives for playing digital games. Media Psychology, 19(1), 101-125. https://doi.org/10.1080/15213269.2014.902318 
Demetrovics, Z., Urbán, R., Nagygyörgy, K., Farkas, J., Zilahy, D., Mervó, B., \& Harmath, E. (2011). Why do you play? The development of the motives for online gaming questionnaire (MOCQ). Behavior Research Methods, 43(3), 814-825. https://doi.org/10.3758/s13428-011-0091-y

Dijital oyun sektörü raporu [Digital Game Industry Report] (Rep.) (2016). Turkey: Ankara Regional Innovation Strategy. Retrieved July 15, 2018, from http://www.ankaraka.org.tr/archive/files/yayinlar/ankaraka-dijital-oyun-sektoru.pdf

Eglesz, D., Feteke, I., Kiss, O. E., \& Izso, L. (2005). Computer games are fun? On professional games and players' motivations. Educational Media International, 42(2), 117-124. https://doi.org/10.1080/09523980500060274

Elliott, L., Ream, G., McGinsky, E., \& Dunlap, E. (2012). The contribution of game genre and other use patterns to problem video game play among adult video gamers. International journal of mental health and addiction, 10(6), 948-969.

Ferguson, C. J., \& Olson, C. K. (2013). Friends, fun, frustration and fantasy: Child motivations for video game play. Motivation and Emotion, 37(1), 154-164. https://doi.org/10.1007/s11031-012-9284-7

Fraenkel, J. R., Wallen, N. E., \& Hyun, H. H. (2012). How to design and evaluate research in education (8th ed.). New York: McGraw-Hill.

Frederick, C., \& Ryan, R. M. (1993). Differences in motivation for sport and exercise and their relations with participation and mental health. Journal of Sport Behavior, 16(3), 124-146.

Gagné, M., \& Deci, E. L. (2005). Self-determination theory and work motivation. Journal of Organizational Behavior, 26(4), 331-362.

Gaming-Statistics \& Facts. (2019). Retrieved September 12, 2019, from https://www.statista.com/topics/1680/gaming /

Gaming-Statistics \& Facts. (n.d.). Retrieved September 12, 2019, from https://www.statista.com/outlook/203/113/video-games/turkey\#market-age

Gee, J. P. (2003). What video games have to teach us about learning and literacy. New York: Palgrave Macmillan.

Gentile, D. A., \& Anderson, C. A. (2003). Violent video games: The newest media violence hazard. In D. Gentile (Ed.), Media violence and children (pp. 131-152). Westport, CT: Praeger.

Greenberg, B. S., Sherry, J., Lachlan, K., Lucas, K., \& Holmstrom, A. (2010). Orientations to video games among gender and age groups. Simulation \& Gaming, 41(2), 238-259. https://doi.org/10.1177/1046878108319930

Hair, J. F., Black, W. C., Babin, B. J., Anderson, R. E., \& Tatham, R. L. (2006). Multivariate data analysis (6th ed.). Uppersaddle River: Pearson Prentice Hall.

Hamari, J. (2015). Why do people buy virtual goods? Attitude toward virtual goodpurchases versus game enjoyment. International Journal of InformationManagement, 35(3), 299-308.

Hamari, J., \& Keronen, L. (2017). Why do people play games? A meta-analysis. International Journal of Information Management, 37(3), 125-141.

Hamlen, K. R. (2011). Children's choices and strategies in video games. Computers in Human Behavior, 27(1), 532-539. https://doi.org/10.1016/j.chb.2010.10.001

Heeter, C., Lee, Y. H., Medler, B., \& Magerko, B. (2011). Beyond player types: gaming achievement goal. In Proceedings of the 2011 ACM SIGGRAPH Symposium on Video Games (pp. 43-48).

Hodgins, H. S., \& Knee, C. R. (2002). The integrating self and conscious experience. In E. L. Deci \& R. M. Ryan (Eds.), Handbook of self-determination research (pp. 87-100). Rochester, NY: University of Rochester Press. 
Hoeft, F., Watson, C. L., Kesler, S. R., Bettinger, K. E., \& Reiss, A. L. (2008). Gender differences in the mesocorticolimbic system during computer game-play. Journal of $\begin{array}{lll}\text { Psychiatric Research, 253-258. } & \text { 42(4), }\end{array}$ https://doi.org/10.1016/j.jpsychires.2007.11.010

Hoffman, B., \& Nadelson, L. (2010). Motivational engagement and video gaming: A mixed methods study. Educational Technology Research and Development, 58(3), 245-270. https://doi.org/10.1007/s11423-009-9134-9

Hsieh, Y. H., Lin, Y. C., \& Hou, H. T. (2016). Exploring the role of flow experience, learning performance and potential behavior clusters in elementary students' game-based learning. Interactive Learning Environments, 24, 178-193.

Interactive Software Federation of Europe. (2012). Videogames in Europe: Consumer study. Retrieved from https://www.isfe.eu/videogames-europe-2012-consumer-study.

İnal, Y., \& Çağıltay, K. (2005). İlköğretim öğrencilerinin bilgisayar oyunu oynama alışkanlıkları ve oyun tercihlerini etkileyen faktörler [Elementary Students' Habits of Playing Computer Games and Factors Affecting Game Preferences]. Ankara Özel Tevfik Fikret Okulları, Eğitimde Yeni Yönelimler II Eğitimde Oyun Sempozyumu, [Ankara Private Tevfik Fikret Schools- New Trends in Education II Game Symposium in Education]Ankara, 71-74.

Johnson, D., Gardner, J., \& Sweetser, P. (2016). Motivations for videogame play: Predictors of time spent playing. Computers in Human Behavior, 63, 805-812. https://doi.org/10.1016/j.chb.2016.06.028

Johnson, S. (2005). Everything bad is good for you. New York: Riverhead Books.

Jones, G. (2002). Killing monsters: Why children need fantasy, super heroes, and makebelieve violence. New York: Basic Books.

King, D., \& Delfabbro, P. (2009). Motivational difference in problem video game play. Journal of Cybertherapy and Rehabilitation, 2(2), 139-150.

Koestner, R., \& Losier, G. (2002). Distinguishing among three types of highly motivated individuals. In E. L. Deci \& R. M. Ryan (Eds.), Handbook of self-determination research (pp. 101-122). Rochester, NY: University of Rochester press.

Lafrenière, M. A. K., Verner-Filion, J., \& Vallerand, R. J. (2012). Development and validation of the Gaming Motivation Scale (GAMS). Personality and Individual Differences, 53(7), 827-831. http://dx.doi.org/10.1016/j.paid.2012.06.013

Legault, L. (2017). Self-determination theory. Encyclopedia of personality and individual differences, 1-9. Doi:10.1007/978-3-319-28099-8_1162-1

Lowrie, T., \& Jorgensen, R. (2011). Gender differences in students' mathematics game playing. Computers \& Education, 57, 2244-2248.

Malone, T. W. (1980). What makes things fun to learn? A study of intrinsically motivating computer games. California: Palo Alto Research Center.

Malone, T. W., \& Lepper, M. R. (1987). Making learning fun: A taxonomy of intrinsic motivations in learning. In R. E. Snow \& M. J. Farr (Eds.), Aptitude, learning and instruction: vol. 3. Conative and affective process analyses (pp. 223-253). Hillsdale, NJ: Lawrence Erlbaum.

Mills, D. J., Milyavskaya, M., Health, N. L., \& Derevensky, J. L. (2018). Gaming motivation and problematic video gaming: The role of needs frustration. European Journal of Social Psychology, 48(4), 551-559. doi:10.1002/ejsp.2343

Newzoo (2018) Retrieved May 21, 2018, from https://newzoo.com/insights/articles/globalgames-market-reaches-137-9-billion-in-2018-mobile-games-take-half/

Newzoo (2018) Retrieved May 21, 2018, from https://newzoo.com/insights/articles/theglobal-games-market-will-generate-152-1-billion-in-2019-as-the-u-s-overtakes-chinaas-the-biggest-market/ 
Olson, C. K. (2010). Children's motivations for video game play in the context of normal development. Review of General Psychology, 14, 180-187.

Pala, F. K., \& Erdem, M. (2015). Dijital oyun tercihi ve oyun tercih nedeni ile cinsiyet, sinif düzeyi ve öğrenme stili arasındaki ilişkiler üzerine bir çalışma. Ahi Evran Üniversitesi Kırşehir Eğitim Fakültesi Dergisi, 12(2), 53-71.

Paraskeva, F., Mysirlaki, S., \& Papagianni, A. (2010). Multiplayer online games as educational tools: Facing new challenges in learning. Computers \& Education, 54, 498-505.

Rehbein, F., Staudt, A., Hanslmaier, M., \& Kliem, S. (2016). Video game playing in the general adult population of Germany: Can higher gaming time of males be explained by gender specific genre preferences? Computers in Human Behavior, 55, 729-735.

Ryan, R. M. (1995). Psychological needs and the facilitation of integrative processes. Journal of Personality, 63(3), 397-427. https://doi.org/10.1111/j.1467-6494.1995.tb00501.x.

Ryan, R. M., \& Deci, E. L. (2000). Self-Determination Theory and the facilitation of intrinsic motivation, social development, and well-being. American Psychologist, 55(1), 68-78. https://doi.org/10.1037/0003-066X.55.1.68

Ryan, R. M., \& Deci, E. L. (2017). Self-Determination Theory: Basic Psychological Needs in Motivation, Development, and Wellness. New York, NY: Guilford Press.

Ryan, R. M., Patrick, H., Deci, E. L., \& Williams, G. C. (2008). Facilitating health behaviour change and its maintenance. Interventions based on self-determination theory. The European Health Psychologist, 10, 2-5.

Ryan, R. M., Rigby, C. S., \& Przybylski, A. (2006). The motivational pull of video games: A self-determination theory approach. Motivation and Emotion, 30(4), 344-360. https://doi.org/10.1007/s11031-006-9051-8

Seaborn, K., \& Fels, D. I. (2015). Gamification in theory and action: A survey. International Journal of human-computer studies, 74, 14-31.

Sherry, J. L., Lucas, K., Greenberg, B. S., \& Lachlan, K. (2006). Video game uses and gratifications as predictors of use and game preference. In P. Vorderer \& J. Bryant (Eds.), Playing video games: Motives, responses, and consequences (pp. 213-224). London, UK: Routledge.

Tamborini, R., Bowman, N. D., Eden, A., Grizzard, M., \& Organ, A. (2010). Defining media enjoyment as the satisfaction of intrinsic needs. Journal of Communication, 60(4), 758-777. https://doi.org/10.1111/j.1460-2466.2010.01513.x.

Vallerand, R. J. (1997). Toward a hierarchical model of intrinsic and extrinsic motivation. In M. P. Zanna (Ed.), Advances in experimental social psychology (pp. 271-360). New York: Academic Press.

Vallerand, R. J. (2007). A hierarchical model of intrinsic and extrinsic motivation for sport and physical activity. In M. S. D. Hagger \& N. L. D. Chatzisarantis (Eds.), Selfdetermination theory in exercise and sport (pp. 255-279). Champaign, IL: Human Kinetics.

Wouters, P., van Nimwegen, C., van Oostendorp, H., \& van Der Spek, E. D. (2013). A metaanalysis of the cognitive and motivational effects of serious games. Journal of Educational Psychology, 105, 249-265. doi:10.1037/a0031311

Yang, J. C., \& Quadir, B. (2018). Individual differences in an English learning achievement system: Gaming flow experience, gender differences and learning motivation. Technology, Pedagogy and Education, 27(3), 351-366 